\title{
ANALISIS IDIOMATIK PADA NOVEL DUA BARISTA KARYA NAJHATY SHARMA
}

\author{
Syafi' Junadi ${ }^{1}$, Atina Khoirun Nisa ${ }^{2}$ \\ e-mail: junaidisyafi@iaida.ac.id ${ }^{1}$, atinasyantik@gmail.com ${ }^{2}$ \\ Prodi Tadris Bahasa Indonesia \\ IAI Darussalam Blokagung Banyuwangi
}

\begin{abstract}
Abstrak
Dalam penelitian ini disebutkan bahwa ada dua jenis makna idiomaotik yaitu idiomtik penuh dan idiomatik sebagian. Penelitian ini bertujuan untuk menganalisis makana Idiomatik bentuk dan juga jenis idiomatik bahasa indonesia . jenis idiomatik yang terdapat dalam novel Dua Barista karna Najhati Sharma tahun 2020 ada dua macam yaitu Idiomatik sebagian dan idiomatik penuh. Jenis penelitian ini adalah kualitatif dengan menggunakan metode analisis data.Oleh karena itu peneliti mengambil judul "Makna idiomatik pada novel Dua Barista karya Najhay Sharma". Analisis Data yang digunakan Dengan Menggunakan teknik Membaca dan mencatat novel Dua Barista Karya Najhaty Sharma. Hasil penelitian ini menunjukkan bahwa terdapat jenis idiom penuh dan idiom sebagian dalam novel Dua Barista karaya Najhaty Sharma. Idiom penuh ditemukan sebanyak sebelas idiom sebagian dan sebelas idiom penuh yaitu, penyakit bersarang, pekantnya malam, membanting tulang, khodimah, gubuk sederhana, kabar burung,berbinar binar bak purnam, badanku kurus laksana huruf alif,batang hidung nya,ribuan kaki do'a. Dari data analisis tersebut ditemukan sebelas idiom penuh dan sebelas idiom sebagian. Jadi kesimpulan dari penelitian ini adalah tentang analisis idiomatik yang didalamnya membahasa tentang jenis idiomatik dan makna idiomatik yang terdapat dlam novel Dua Barista karya najhaty sharma tahun 2020.
\end{abstract}

Kata Kunci: novel, idiomatik, makna kata, semantik.

\begin{abstract}
Researchers limit the problems analyzed about the type of idiomatic and the meaning of the idiomatic. In this study, it is stated that there are two types of idiomaotic meanings, namely full idiom and partial idiom. This study aims to analyze idiomatic forms and types of idiomatic Indonesian. There are two types of idiomatic contained in the novel Dua Barista because Najhati Sharma in 2020, namely partial idiomatic and full idiomatic. This type of research is qualitative using data analysis methods. Therefore, the researcher took the title "The idiomatic meaning of the novel Dua Barista by Najhay Sharma". Data analysis used by using reading techniques and recording the novel Dua Barista by Najhaty Sharma. The results of this study indicate that there are full idiom types and partial idioms in the novel Dua Barista karaya Najhaty Sharma. Full idioms were found as many as eleven partial idioms and eleven full idioms, namely, nesting disease, night pekantnya, toil, khodimah, simple huts, rumors, shining like the full moon, my body is thin like the letter alif, the bridge of the nose, thousands of feet of prayer. From the data analysis, it was found that eleven full idioms and eleven partial idioms were found. So the conclusion of this study is about idiomatic analysis, which discusses idiomatic types and idiomatic meanings contained in the novel Dua Barista by Najhaty Sharma in 2020.
\end{abstract}

Keyword: novel, idiomatic, word meaning, semantics. 


\section{A. Pendahuluan}

Bahasa merupakan alat komunikasi untuk menyampaikan ide, gagasan, pendapat, serta perasaan kepada orang lain. Selain komunikasi, bahasa juga dituangkan dalam bentuk tulisan dan merupakan salah satu alat komunikasi kedua yang penting guna menciptakan komunikasi secara tidak langsung oleh sang penulis buku dan pembaca. Bahasa juga merupakan salah satu budaya yang sangat tinggi nilainya, karena dengan bahasa pula manusia dimungkinkan dapat berkembang dan mengabstraksikan berbagai gejala yang muncul disekitar. jelas bahasa sangat penting perannya dalam kehidupan sosial dan boleh dikatakan manusia berbahasa setiap hari mulai dari bangun tidur sampai tidur lagi. Setiap bahasa mempunyai kekhasannya.

Bahasa yang digunakan dalam berkomunikasi adalah bentuk lisan dan tulisan. Seringkali suatu maksud tertentu disampaikan secara tak langsung. Banyak pertimbangan yangmenyebabkan penyampaian maksud secara tak langsung, di antaranya untuk menghindari ketersinggungan seseorang dengan adanya ujaran tertentu. Dapat dikatakan bahwa hal ini terkait dengan cara masyarakat penutur bahasa tersebut mengungkapkan sesuatu. Oleh karena itu tidak jarang dalam bentuk-bentuk komunikasi tersebut kita memakai ungkapan khusus untuk menyampaikan sebuah pesan. Ungkapan khusus ini biasa dikenal dengan Idiom. Idiom berkaitan dengan kultur masyarakat yang bersangkutan. Ungkapan khusus ini berbeda dari negara satu dengan negara lainnya.

Menurut Abdul Chaer dalam bukunya Semantik 2003 menyatakan bahwa bahasa tumbuh dan dibutuhkan dalam segala aspek kehidupan masyarakat yang meliputi kegiatan bermasyarakat seperti perdagangan, pemerintahan, kesehatan, pendidikan, keagamaan, dan sebagainya. Dan emosi seseorang kepada orang lain. (Chaer, 2003: 38). Menurut Sudaryanto (1990: 21) bahasa pada dasarnya memang merupakan alat atau sarana untuk komunikasi antar manusia. Bahasa juga merupakan salah satu ciri yang membedakan manusia dengan mahluk lain. Hal itu disebabkan karena manusia mempunyai kemampuan untuk berfikir dan kemampuan untuk mengembangkan akal budinya. Dengan kemampuan itu manusia menggabungkan satu alat buntuk berkomunikasi duna mengungkapkan pikiran, perasaan, ataupun keinginanya yaitu bahasa.

Bahasa adalah alat komunikasi yang terkait erat dengan bidang ilmu bahasa semantik yang merupakan sauatu cabang ilmu linguistik yang mempelajari mengenai makna bahasa. Semantik adalah ilmu tentang makna yang merupakan suatu komponen bunyi dan gramatika. Semantik merupakan bagian linguistik yang menjadi makna dari bahasa. Semantik menelaah lambang - lambang atau tanta - tanda yang menyatakan 
makna, hubungan makna satu dengan makna yang lain dan dan pengaruhnya terhadap manuisa dan masyarakat. Oleh karena itu semantik mencakup makna - makna kata, perkembangan dan perubahannya, dan apa sebabnya terjadi perubahan makna dalam sejarah bahasa ( Suwardi, 2011:2)

Makna merupakan istilah yang ambigu dan paling kontroversial dalam teori tentang bahasa. Maka dapat dibedakan berdasarkan beberapa kreteria antara lain berdasarkan jenis semantiknya, nilai rasa, referensi dan ketepatan makna(Suwandi,2011:79). Maka dapat pula ditinjau dari pendekatan analitik atau referensial, yakni pendekatan yang mencari esensi makna dengan cara menguraikan. Pendekatan tersebut berbeda dengan pendekatan operasional yang mempelajari kata dalam penggunaanya, menekankan bagaimana kata secara operasional. Masalah kebahasaan ini tidak terlepas dari kehiduapan masyarakat penduduknya. Dalam kehidupan masyarakat indonesia telah terjadi berbagai perubahan, baik sebagai akibat tatanan kehidupan dunia yang baru, globalisasi, maupun sebagai dampak perkembangan teknologi informasi yang sangat pesat. perkembangan bahasa begitu luas, apalagi sekarang didukung dengan perkembangan teknologi khususnya media elektronik yang semakin meluas perkembangan nya, kosa kata dalam bahasa Indonesia begitu pesat.

Berbicara tentang idiom, penggunaan idiom dalam kalimat bahasa Indonesia perlu menjadi fokus perhatian, karena kenyataan menunjukkan bahwa para pengguna bahasa banyak yang tidak memperhatikan pemakaian bahasa Indonesia dengan baik. Mereka tidak memiliki rasa tanggung jawab terhadap kemantapan pemakaian bahasa Indonesia baku. Mereka sering menambah atau mengurangi penggunaan kata atau kalimat dengan sekehendak hatinya atau mengubah penggunaan idiom atau ungkapan sehingga menimbulkan pengertian dan pemaknaan yang keliru. Oleh karena itu, tidaklah mengherankan jika sering ditemukan kesalahan penggunaan bahasa Indonesia, baik dalam bahasa tulis maupun bahasa lisan. Mereka sering menambah atau mengurangi kalimat sendiri.

Idiom sering digunakan oleh penutur bahasa dalam berkomunikasi dengan masyarakat luas. Penggunaan idiom ini sengaja dilakukan terutama untuk menyatakan sesuatu secara tidak langsung kepada lawan bicara, hanya dengan menyatakan di luar konteks kata yang lebih mudah dicerna dan dimengerti oleh pendengar tanpa adanya kesalahan persepsi antara penutur dan petutur. Misalnya, kata pencuri lebih halus kedengarannya bila menggunakan kata panjang tangan. Salah satu bagian idiom yaitu ungkapan tetap. Ungkapan tetap merupakan pasangan kata yang teradat, yang pemakaiannya tidak boleh dipisahkan dengan kata yang mengikutinya. Seperti kata sesuai 
dengan, dalam penulisan kata ini seringkali didapati hanya menggunakan kata sesuai tanpa diikuti oleh kata dengan. Pada hal seharusnya kata ini sesuai selalu bersama dalam setiap penulisannya agar makna yang ditimbulkannya dimengerti oleh pembaca atau pendengar.

Penggunaan idiom dapat diawali dengan pemahaman isi teks berita. Berita dalam media online sebagai objek untuk melatih penutur bahasa dalam meningkatkan kegiatan membaca menemukan ungkapan idiom yang ada dalam berita yang dibacanya . Sekaligus Idiom yang digunakan dalam penulisan berita ataupun bacaan lain mempunyai dua jenis idiom yaitu penuh dan sebagian. Dengan demikian, penutur bahasa akan mudah menemukan idiom. Dari penjelasan diatas mengenai makna idiom, maka penelitian ini akan menganalisis penggunaan idiom dalam novel Dua Barista Karya Najhati Sharman tahun 2020 yang ditinjau dari bentuk dan makna idiom yang ada dalam novel tersebut.

\section{B. Metode Penelitian}

Jenis penelitian ini adalah penelitian kualitatif besifat diskriptif . bogdan dan Taylor ( 1975: 5 Dalam Meloeng 2014: 4) Mendefinisikan metdelogi kualitatif sebagai prosedur penelitian yang menghasilkan data deskriptif. Sejalan dengan penjelasan itu, penelitian ini bertujuan untuk menganalisis makna Idiomatik dalam novel Dua Barista karya Najhaty Sharma tahub 2020. Untuk mendapatkan data dari penelitian tentang Idiomatik dalam Novel Dua Barista Karya Najhaty Sarma, naka dibuatlah data untuk membedakan makna idiomatic penuh dan makna idiomatic sebagian.

Dalam penelitian ini agar menghasilkan penelitian yang didapati berarti serta mempuntai tujuan dan manfaat yang jelas, maka seperti yamg telah dijabarkan pada rumusan masalah diatas penelitian ini mempunyai tujuan sebagai berikut.

1. Untuk mengetahui jenis makna idiomatik dalam novel Dua Barista karya Najhati Sharman

2. Untuk mengetahui analisis makna idiomatik dalam novel Dua Barista karya Najhati Sharman tahun 2020 .

3. Untuk mengetahui makna idiomatik dalam novel Dua Barista karya Najhari Sharnma tahun 2020 . 


\section{Hasil dan Pembahasan}

Tabel 1.1

Makna idiomatik penuh dan makna idiomatik sebagian dalam novel Dua Barista Karya Najhaty Sharma tahun 2020

\begin{tabular}{|c|c|c|c|c|}
\hline \multirow{2}{*}{ No } & \multirow{2}{*}{ kalimat dalam novel } & \multirow{2}{*}{ Idiom } & \multicolumn{2}{|c|}{ jenis idiom } \\
\hline & & & sebagian & Penuh \\
\hline 1 & $\begin{array}{l}\text { sudah lama penyakit ini bersarang dalam } \\
\text { tubuh Mazarina }\end{array}$ & penyakit bersarang & & $\checkmark$ \\
\hline 2 & $\begin{array}{l}\text { siapa yang menyiapkan semua ini, aku } \\
\text { takjub }\end{array}$ & Takjub & $\checkmark$ & \\
\hline 3 & kenapa dia berdiri mematung & berdiri mematung & $\checkmark$ & \\
\hline 4 & $\begin{array}{l}\text { dari tadi Maysaroh tidak kelihatan batang } \\
\text { hidungnya }\end{array}$ & batang hidungnya & $\checkmark$ & \\
\hline 5 & $\begin{array}{l}\text { pesantren adalah lembaga pendidikan } \\
\text { yang didirikan diatas ribuan kaki do'a }\end{array}$ & ribuan kaki do'a & & $\checkmark$ \\
\hline 6 & mengadopsi anak bukanlah solusi terbaik & mengadopsi & & $\checkmark$ \\
\hline 7 & $\begin{array}{l}\text { Maysaroh berasal dari kalangan orang } \\
\text { yang suka membantingtulang }\end{array}$ & Membanting tulang & & $\checkmark$ \\
\hline 8 & $\begin{array}{l}\text { perempuan itu dulu sering melihatku } \\
\text { membuatkan kopi untuk suamiku, dan } \\
\text { kini dia sudah mempraktekan sendiri dia } \\
\text { juga ingin menjadi BARISTA }\end{array}$ & Barista & & $\checkmark$ \\
\hline 9 & $\begin{array}{l}\text { andai saja kamu tau cinta itu serupa botol } \\
\text { dan tutupnya }\end{array}$ & $\begin{array}{l}\text { cinta itu serupa botol dan } \\
\text { tutupnya }\end{array}$ & & $\checkmark$ \\
\hline 10 & $\begin{array}{l}\text { "tentang poligami ini bukan hanya kamu } \\
\text { saja yang resah ning" }\end{array}$ & Poligami & & $\checkmark$ \\
\hline 11 & $\begin{array}{l}\text { Maysasoh memang ahli masak, karena } \\
\text { dulu dia adalah bagian dari khodam } \\
\text { bunyai }\end{array}$ & khodam bunyai & $\checkmark$ & \\
\hline 12 & $\begin{array}{l}\text { aku terbiasah meraih mimpi dari fase ke } \\
\text { fase }\end{array}$ & fase ke fase & $\checkmark$ & \\
\hline 13 & $\begin{array}{l}\text { sebenarnya ning Mazarina itu memiliki } \\
\text { hati yang sangat mulia hati yang mulia }\end{array}$ & & $\checkmark$ & \\
\hline 14 & $\begin{array}{l}\text { hingga akhirnya entah dimulai darimana } \\
\text { dan siapa wacana poligami itu benar } \\
\text { benar dihembuskan dalam kehidupanku }\end{array}$ & Hembuskan & & $\checkmark$ \\
\hline 15 & $\begin{array}{l}\text { lekaki paruh baya itu dsatang tergopoh } \\
\text { gopoh mencium tangan ku }\end{array}$ & $\begin{array}{l}\text { lelagi paruh baya dan } \\
\text { tergopoh gopoh }\end{array}$ & & $\checkmark$ \\
\hline 16 & $\begin{array}{l}\text { ia sudah piawai melebur didapus saat } \\
\text { masak masak seperti ini }\end{array}$ & piawai & & $\checkmark$ \\
\hline 17 & $\begin{array}{l}\text { cinta adalah dunia yang adapat dinikmati } \\
\text { oleh sang pecipta hingga hal hal kecil } \\
\text { menjadi nampak, hingahal hal kecil } \\
\text { menjadi nampak, hal hal penting menjadi } \\
\text { berarti, gubuk sederhana menjadi istana }\end{array}$ & $\begin{array}{l}\text { gubuk sederhana menjadi } \\
\text { istana }\end{array}$ & $\checkmark$ & \\
\hline 18 & $\begin{array}{l}\text { Mey selalu memiliki cara tangkas dalam } \\
\text { menyelesaikan urusanya domestik }\end{array}$ & cara tangkas & & $\checkmark$ \\
\hline 19 & $\begin{array}{l}\text { tetiba binar mata gus Ahvas meredup, } \\
\text { teringat sesorang yang jauh disana } \\
\text { berjarak puluhan kilo meter }\end{array}$ & berjarak puluhan kilo meter & $\checkmark$ & \\
\hline 20 & kabar burung memamg begitu & kabar burung & $\checkmark$ & \\
\hline 21 & $\begin{array}{l}\text { kerinduan ini membuatku resah dan gelis } \\
\text { sehingga badanku urus laksana huruf alif } \\
\text { yang tak berharakat }\end{array}$ & $\begin{array}{l}\text { badanku kurus laksana huruf } \\
\text { aif }\end{array}$ & $\checkmark$ & \\
\hline 22 & $\begin{array}{l}\text { mata Mazarina berbinar binar bak } \\
\text { purnama }\end{array}$ & berbinar binar bak purnama & $\checkmark$ & \\
\hline
\end{tabular}


Tabel 1.2

Persentase temuan Idiomatik dalam novel Dua Barista Karya Najhati Sharma tahun 2020

\begin{tabular}{|c|c|c|}
\hline No & Idiomatik & Jumlah \\
\hline 1. & Idiomatik Penuh & 11 \\
\hline 2. & Idiomatik Sebagian & 10 \\
\hline & Jumlah & $\mathbf{2 1}$ \\
\hline
\end{tabular}

Dari hasil penemuan diatas, penulis menyebutkan bahwa ada 21 temuan idiomatik dalam novel Dua Barista Karya Najhaty Sharma tahun 2020.

Dua Barista merupakan novel yang diangkat dari kisah non fiksi. Sebuah kisah yang mengajarkan bagaimana mengolah rasa dan perasaan atas kehidupan yang dialaminya. Dalam kehidupan pesantren yang kental dengan agama dan tradisi yang islami dalam kehidupan seorang wanita, setelah menjadi seorang anak dan istri menjadi ibu adalah tahapan berikutnya yang sangat dinanti. Dibanyak tradisi masyarakat, kesempurnaan seorang wanita dianggap beruntung pada kemampuanya memberikan keteruanan. Banyak kasus yang terjadi dalam kehiduan seorang wanita diceraikan atau dipoligami karena mandul. Tak terkecuali tokoh utama dalam novel ini.

Makna Idiomatik yang terdapat dalam Novel Dua Barista dijadikan reverensi dalam acuan pembuatan penelitian ini, makna idiomatik yang belum begitu banyak diketahui dan dimengerti oleh masyarakat berikut ini uraian mengenai makna idiomatik yang terdapat dalam novel Dua Barista karya Najhati Sharma tahun 2020 antara lain :

"penyakit ini bersarang dalam tubuh mazarina" (Hal:9)l kalimat penyakit bersarang makna aslinya yaitu "sudah lama diderita dalam tubuh mazarin" bentuk idiom dalam kalimat tersebut yaitu makna idiomatik sebagian, karna maknanya masing-masing tergambar dari 
salah satu unsur membentuknya. Sedangkan makna idiomatik yang mengungkapkan makna idiomatik penuh adalah dalam kalimat seperti ini :

"andai saja kamu tau cinta itu serupa botol dan tutupnya"(hal:25)

kalimat seperti itu termasuk dalam idiom atik penuh karena makananya sama sekali tidak tergambar dari unsurnya. Dalam idiomatik penuh makna sudah menyatu dan tidak dapat di ditafsirkan dengan makna pembentuknya.

“siapa yang menyiapkan ini semua aku takjub” kalimat takjub dalam makna idiomatik masuk makna idiom sebagian, karna masing masing maknanya tergambar dari salah satu unsur unsur pembentuknya, dan masih memiliki makna leksikal.

"kenapa dia berdiri mematung" kutipan kalimat berikut mengambarkan makna idiomatik sebagian, karna dalam kalaimat tersebut sudah tergambarkan makna dari salah satu unsur pembentuknya.

"pesantren adalah lembaga pendidikan yang didirikan diatas ribuan kaki doa" kalimat berikut menunjukan makna idomatik penuh karna maknanya sama sekali tidak tergambarkan dari unsur unsurnya.

"Mengadopsi anak bukanlah solusi" Kalimat mengadopsi termasuk dalam makna idiomatik penuh.

“maysaroh berasal dari kalangan orang yang suka membanting tulang” kata membanting tulang masuk dalam makna idiomatik penuh karna maknanya sama sekali tidak tergambarkan lagi unsur unsurnya.

“Baru kusadari pekatnya malam begitu kosong (hal:21)” Kalimat "pekatnya malam" termasuk dalam makna idiomatik penuh.

“perempuan itu dulu sering melihat ku membuatkan kopi untuk suamiku, dan kini dia sudah mempraktekanya sendiri dia juga ingin menjadi BARISTA" kalimat berikut menunjukan makna idiomatik sebagian. Karna maknanya sudah tergambar dari salah satu unsur pembentuknya. 
"andai saja kamu tau cinta itu serupa botol dan tutupnya"(hal:25)

Kalimat seperti yang ditulis diatas ini menunjukan makna idiomatik penuh, karna makna katanya tidak terganbarkan dari unsur unsur pembentuknya.

"tentang poligami ini bukan hanya kamu yang resah ning"(hal:25) kalimat ini mengandung makna idiomatik penuh karna maknanya sudah dapat digambarkan dari unsur unsur penbentuknya.

maysaroh memang ahli masak,karena dulu dia adalah bagian dari khodimah bunyai kalimat tersebut menunjukan makna idiomatik penuh karna maknanya dapat digambarkan dari u8nsur unsur pembentuknya.

“aku terbiasa meraih mimpi dengan sabar dari fase ke fase”(hal:50) kalimat dari fase ke fase menunjukan makna idiomatik sebagian. Karna makna katanya sudah tergambarkan dari salah satu unsur pembentuknya.

"sebenarnya ning mazarina itu memiliki hati yang mulia" kalimat seperti ini menunjukan makna idiomatik sebagian karna sudah bisa dilihat bahawa maknanya masing masing tergambarkan dari salah satu unsur pembentuknya.

"Hingga akhirnya entah dimulai dari mana dan siapa, wacana poligami itu benarbenar dihembuskan dalam kehidupanku” Kalimat ini menunjukan makna idiomatik sebagian, Karna makna katanya sudah tergambarkank dari unsur unsur pembentuk kalimat nya.

lekaki paruh baya itu datang tergopoh-gopoh hendak mencium tanganku (hal:58) kalimat seperti itu sudah menggambarkan makna idiomatik sebagian karna maknanya katanya masing masing tergambarkan dari slah satu unsurnya.

“ia sudah piawai melebur didapur saat masak masak besar seperti khataman” kalimat tersebut menggambarkan makna idiomatik sebagian. Karna maknannya sudah tergambarkan dari salah satu unsur unsurnya.

“Cinta adalah dunia yang dapat dinikmati oleh sang pencinta hingga hal hal kecil menjadi nampak, hal hal tak penting menjadi” 
Kalimat diatas ini menunjukan idiomatik penuh karna maknanya tidak dapat tergambarkan dari unsur unsurnya .

"Kabar burung memamng begitu"

Kalimat diatas metuakan idiom sebagian karna maknanya masing masing tergambar dari salah satu unsur pembentuknya.

"Kerinduan ini membuatku resah dan gelisa, hingga badanku kurus laksana huruf alif yang tak berharokat"

Kalimat diatas menunjukan idiomatik penuh karena maknaya masing masing tidak dapat tergambarkan dari unsurnya.

"Mata Mazarina berbinar bina bak purnama"

Kalimat diatas menunjukan makna idiom sebagian karna makna aslinya masih dapat digambarkan dengan unsur unsur pembentuknya.

\section{Kesimpulan Dan Saran}

Berdasarkan hasil analisis menganai makna idiomatik yang terdapat dalam Novel Dua barista karya Najhati Sharma tahun 2020 yang telah dijabarkan di atas maka dapat ditarik kesimpulan sebagai berikut.

Makna idiomatik yang terdapat dalam novel Dua Barista karya Najhati Sharma tahun 2020 yang diananlisis saat ini berjumblah dua puluh kutipan . yang terdrii dari sebelas makna idiomatik penuh dan sembilan makna idiomatik sebagiayan. Dari dua jenis bagian idiomatik telah penulis simpulkan bahwa ada beberapa makna idiomatik yang belum dapat dipahami oleh masyarakat. Mereka hanya sekilas tau tentang apa itu makna idiomatik sebenarnya. Maka dari itu peneliti mengambil kajian linguistik dengan materi yang diambil makna idiomatik guna memberikan referensi atau acuan untuk untuk dapat dijadikan tambahasan pemahaman dan wawasan. 
Ditijau dari segi spikologi sastra pada tokoh utama dalam novel Dua Barista karya Najhati Sharma tahun 2020. Bahwa setiap tindakan dan perkataan yang di lakukan tokoh utama salalu didasarkan perasaan dan ego. Tokoh utama menggambarkan sifatnya dengan lemah lembut dan penuh perasaan. Dua tokoh yang berperan dalam novel Dua barista karya Najhati Sharma tahun 2020.

Berdasarkan hasil penelitian, pembahasan, kesimpulan yang dilakukan dalam novel Dua Barista karya Najhati Sharma tahun 2020 , maka diajukan beberapa saran sebagai berikut:

1. Kepada pembaca diharapkan tidak hanya mengetahui isi sebuah karya sastra yang terdapat dalam novel Dua Barista karya, tetapi juga mengetahui amanat pesan yang ada dalam novel tesebut.

2. Untuk mahasiswa dapat dijadikan tambahan pemahaman dan wawasan guna untuk referensi kedepan dalam melaksanakan penelitian selanjutnya

3. Diharapkan untuk semua terutama pengajar baik guru maupun calon guru bahasa Indonesia skripsi ini dapat menjadi sebagai alternatif bahan ajar khususnya materi tentang idiomatik.

\section{DAFTAR RUJUKAN}

Abdul. 2009. Pengantar Semantik Bahasa Indonesia. Jakarta: Rineka Cipta.

Alwi, Hasan. dkk. 2001. Kamus Besar Bahasa Indonesia. Jakarta: Balai Pustaka.

Aminuddin. 2003. Semantik: Pengantar Studi tentang Makna. Bandung: Sinar Baru Algensindo

Arikunto, Suharsimi.2010. Prosedur penelitian suatu Pendekatan Praktik. Jakarta :PT. Rineka Cipta.

Chaer, Abdul. 2007. Kamus Idiom Bahasa Indonesia. Ende Flores: Nusa Indah

KBBI online 2020 ( Kamus Besar Bahasa indonesia )

Keraf, Gorys. 2007. Diksi dan Gaya Bahasa. Jakarta: Gramedia Pustaka Utama. 
Mahsun. 2014. “Metode Penelitian Bahasa” Jakarta Raja Wali Pres.

Sharma Najhati. 2020. "Novel Dua Barista". Tegalrejo Jogjakarta. 